$\begin{array}{r}\text { Phinisi Integration Review } \\ \text { Vol. 2, No.1, Februari 2019 Hal 124-136 } \\ \text { Website: http://ojs.unm.ac.id/pir } \\ \text { p-ISSN: 2614-2325 dan e-ISSN: 2614-2317 } \\ \hline\end{array}$

\title{
Pengaruh Model Problem Based Learning Dengan Pendekatan SAINTIFIK Terhadap Hasil Belajar IPS Di SDN 197 Duampanua Kabupaten Pinrang
}

\author{
Sriwahyuni Kadir Putri ${ }^{(1)}$, \\ Program Pascasarjana Jurusan Ilmu Pengetahuan Sosial Universitas Negeri Makassar \\ email: sriwahyunikadir910@gmail.com
}

\begin{abstract}
Abstrak. Penelitian ini bertujuan untuk mengetahui (i) hasil belajar IPS peserta didik Kelas V SDN 197 Duampanua Kabupaten Pinrang melalui Model Problem Based Learning (PBL) dengan Pendekatan Saintifik; (ii) hasil belajar IPS peserta didik Kelas V SDN 197 Duampanua Kabupaten Pinrang melalui Model Problem Based Learning (PBL) dengan Pendekatan Konvensional; (iii) perbedaan hasil belajar IPS peserta didik Kelas V SDN 197 Duampanua Kabupaten Pinrang melalui Model Problem Based Learning dengan Pendekatan Saintifik dan Model Problem Based Learning dengan Pendekatan Konvensional. Jenis penelitian merupakan eksperimen, dengan model Quasi Experimental Design. Instrumen penelitian berupa test hasil belajar (pretest dan posttest), dan lembar kegiatan aktivitas siswa. Data dianalisis dengan menggunakan statistitik deskriptif seperti mendeskripsikan hasil belajar peserta didik. Analisis statistik inferensial (uji-t) digunakan untuk melihat pengaruh Pendekatan Saintifik Dan Model Pembelajaran Based Learning Terhadap Hasil Belajar IPS Peserta Didik melalui program SPSS. Hasil penelitian menunjukkan bahwa (1) hasil belajar IPS peserta didik Kelas V SDN 197 Duampanua Kabupaten Pinrang setelah menggunakan Model Problem Based Learning dengan Pendekatan Saintifik berada pada kategori sangat tinggi (2) hasil belajar IPS peserta didik Kelas V SDN 197 Duampanua Kabupaten Pinrang melalui Model Problem Based Learning (PBL) dengan Pendekatan Konvensional berada pada kategori cukup dan tinggi. (3) terdapat perbedaan hasil belajar IPS peserta didik Kelas V SDN 197 Duampanua Kabupaten Pinrang melalui Model Problem Based Learning dengan Pendekatan Saintifik dan Model Problem Based Learning dengan Pendekatan Konvensional
\end{abstract}

Kata Kunci: Pengaruh Pendekatan Saintifik; Model Problem Based Learning

\begin{abstract}
This study aims to (i) To find out the social studies learning outcomes of Grade V students of SDN 197 Duampanua, Pinrang Regency through the Problem Based Learning (PBL) Model with a Conventional Approach; (ii) To find out the social studies learning outcomes of Grade V students of SD 197 Duampanua Pinrang District through the Problem Based Learning (PBL) Model with a Scientific Approach; (iii) To find out the differences in social studies learning outcomes of Grade 5 students at SD Du 1977 in Pinrang District through a Problem Based Learning Model with a Scientific Approach and a Problem Based Learning Model with a Conventional Approach. This type of research is an experiment, with the Quasi Experimental Design model. This research was conducted to see the effect of the Scientific Approach and Learning Based Learning Model on Student Social Studies Learning Outcomes. The research instrument was a test of learning outcomes (pretest and posttest), and a sheet of student activity activities.
\end{abstract}


Descriptive analysis data to describe the ability of teachers to manage learning, student activities in learning and learning outcomes. Inferential statistical analysis (t-test) is used to see the effect of the Scientific Approach and Learning Based Learning Model on Student Social Studies Learning Outcomes through the SPSS program. The results of the study showed that (1) Social Sciences learning outcomes of Grade V students of SDN 197 Duampanua Pinrang District through the Problem Based Learning Model (PBL) and Conventional Approach were in the low category (2) there was an increase in Social Sciences learning outcomes of Grade V 197 Duampanua District Elementary School Pinrang after using the Scientific Approach and the Problem Based Learning Model. (3) there are influences and differences in social studies learning outcomes of Grade V students of SD Du 1977 in Pinrang District through a Problem Based Learning Model with a Scientific Approach and a Problem Based Learning Model with a Conventional Approach

Keywords: Effect of Scientific Approach; Problem Based Learning Model

\section{PENDAHULUAN}

Pendidikan merupakan hal yang utama dalam proses peningkatan kualitas sumber daya manusia. Melalui pendidikan seorang akan menndapat bekal dalam menghadapi kehidupan di masa mendatang karena dengan pendidikan kehidupan seseorang akan diharapkan akan lebih baik. Seperti yang telah diamanatkan dalam pembukaan UUD 1945 alinea ke-empat, yaitu mencerdaskan kehidupan bangsa. Amanat tersebut dipertegas dalam UUD 1945 Pasal 31 Ayat 3 (amandemen), yakni pemerintah mengusahakan dan menyelenggarakan satu sistem pendidikan nasional, yang meningkatkan keimanan dan ketakwaan serta akhlak mulia dalam rangka mencerdaskan kehidupan bangsa.

Untuk menjalankan amanat itu, maka dalam UU No. 20 Tahun 2003 tentang Sistem Pendidikan Nasional (UU Sisdiknas) Pasal 3 ditetapkan fungsi dan tujuan pendidikan nasional, yaitu mengembangkan kemampuan dan membentuk watak serta peradaban bangsa yang bermartabat dalam rangka mencerdaskan kehidupan bangsa, bertujuan untuk berkembangnya potensi murid agar menjadi manusia yang beriman dan bertakwa kepada Tuhan Yang Maha Esa, berakhlak mulia, sehat, berilmu, cakap, kreatif, mandiri, dan menjadi warga negara yang demokratis serta bertanggung jawab.

Kenyataanya pada SDN 197 Duampanua menunjukkan beberapa permasalahan misalnya proses pembelajaran yang digunakan oleh guru masih monoton meskipun ada sekolah yang telah menggunakan metode pembelajaran yang bervariasi. Selain itu, pembelajaranya juga masih bersifat teacher centered. Kondisi ini terlihat ketika peserta didik cenderung ribut sendiri, kurang memperhatikan penjelasan guru, menyepelekan guru serta mengantuk. Akibatnya hasil belajar IPS menjadi rendah atau nilai yang bagus kurang bisa dipertahankan. Kenyataan ini sangat mengejutkan karena ternyata mata pelajaran IPS masih dirasa sulit oleh peserta didik. Oleh sebab itu, maka peneliti meliht perlunya perubahan dalam proses pembelajaran IPS.

yang telah dilakukanterhadap proses pembelajaran IPS di Kelas V SDN 197 Duampanua kenyataan di lapangan memperlihatkan bahwa terjadi beberaa hal yang tidak sesuai atau seharusnya tidak terjadi dalam proses pembelajaran seperti: (1) kegiatan pembelajaran yang berlangsung kurang mengajak siswa untuk dapat melakukan kegiatan mengamati permasalahan yang berkaitan dengan materi yang dipelajari, baik secara langsung maupun media. (2) siswa kurang aktif dalam proses pembelajaran, seperti kurang memberikan respon terhadap penjelasan guru, jarang bertanya maupun mengemukakan atau mengkomunikasikan pendapatnya karena terbiasa hanya mendengarkan penjelasan guru. (3) tanggung jawab yang dimiliki siswa 
cenderung kurang, hal ini terlihat pada saat berkelompoksiswa sering tidak mengerjakan tugas atau diberi tugas dalam kelompok hanya beberapa siswa yang mengerjakan. (4) disiplin yang dimiliki siswa juga cenderung kurang, hal ini terlihat dari banyaknya siswa yang kurang mempersiapkan diri ketika pembelajaran IPS berlangsung, sehingga saat pembelajaran berlangsung banyak siswa yang tidak mematuhi perintah guru, sering keluar masuk kelas dan terkadang sebagian siswa lupa membawa buku pelajaran.

Dalam hal ini, peneliti mencoba mencari solusi dengan berdiskusi dengan teman sejawat dan melihat teori-teori yang mendukung untuk mengatasi permasalahan tersebut. Solusi yang dapat ditempuh yaitu dengan menggunakan pendekatan pembelajaran yang efektif sehingga memungkinkan terciptanya pembelajaran yang berpusat pada siswa sehingga pembelajaran terasa menyenangkan, tidak membosankan, dan dapat membuat siswa lebih aktif serta karakter siswa pun dapat berkembang. Salah satu pendekatan serta model pembelajaran yang bisa di terapkan untuk dapat meningkatkan hasil belajar siswa adalah dengan menggunakan pendekatan saintifik dengan model pembelajaran PBL.

Diharapkan setelah menggunakan pendekatan saintifik dan model PBL hasil belajar peserta didik menjadi meningkat. Semangat saling menghargai tanpa membedakan ras, agama, gender, golongan, budaya, dan suku dalam kehidupan bermasyarakat, berbangsa dan bernegara akan tercipta sehingga terbentuklah pribadi yang baik yang dapat membawa ke generasi bangsa Indonesiayang berwawasan serta tidak membeda-bedakan siapapun. Berdasarkan uraian diatas, maka peneliti perlu untuk melakukan suatu penelitian dengan judul " Pengaruh Model Problem Based Learning dengan Pendekatan Saintifik Terhadap Hasil Belajar IPS pada Siswa SDN 197 Duampanua kabupaten Pinrang “

Berdasarka latar belakang diatas, rumusan masalah dapat disusun sebagai berikut :

1. Bagaimanakah hasil belajar IPS peserta didik Kelas V SDN 197 Duampanua Kabupaten Pinrang yang diajar melalui Model Problem Based Learning (PBL) dengan Pendekatan Saintifik ?

2. Bagaimanakah hasil belajar IPS peserta didik Kelas V SDN 197 Duampanua Kabupaten Pinrang yang diajar melalui
Model Problem Based Learning (PBL) dengan Pendekatan Konvensional?

3. Apakah terdapat perbedaan hasil belajar IPS peserta didik Kelas V SDN 197 Duampanua Kabupaten Pinrang antara yang diajar melalui Model Problem Based Learning dengan Pendekatan Saintifik dan Model Problem Based Learning dengan Pendekatan Konvensional ?

Atas dasar perumusan masalah di atas, tujuan penelitian ini secara oprasional dirumusan berikut :

1. Untuk mengetahui hasil belajar IPS peserta didik Kelas V SDN 197 Duampanua Kabupaten Pinrang melalui Model Problem Based Learning (PBL) dengan Pendekatan Saintifik.

2. Untuk mengetahui hasil belajar IPS peserta didik Kelas V SDN 197 Duampanua Kabupaten Pinrang melalui Model Problem Based Learning (PBL) dengan Pendekatan Konvensional

3. Untuk mengetahui perbedaan hasil belajar IPS peserta didik Kelas V SDN 197 Duampanua Kabupaten Pinrang antara yang diajar melalui Model Problem Based Learning dengan Pendekatan Saintifik dan Model Problem Based Learning dengan Pendekatan Konvensional.

Dari hasil penelitian diharapkan dapat bermanfaat, khususnya manfaat praktis yaitu bagi peserta didik, guru, dan sekolah. Sedangkan manfaat teoritis antara laian sebagai rujukan dalam penelitian lanjutan IPS.

\section{Hasil Pembelajaran IPS}

\section{a. Hakikat Belajar}

Belajar adalah suatu kegiatan yang tidak dapat dipisahkan dari kehidupan manusia. Belajar dan hasil belajar tidak dapat dipisahkan karena saling adanya keterkaitan. Belajar menunjuk pada sebua proses yang ditandai dengan adanya interaksi antara komponen-komponen pembelajaran.

Cronbach (1954) dalam Sumandi Suryabrata (2011:231), menyatakan bahwa "Learning is shown by a change in behavior as a result of experince". Belajar adalah suatu aktivitas yang ditunjjukan oleh perubahan tingkah laku sebagai hasil dari pengalaman. latihan.

\section{b. Hakikat Hasil Belajar}

Menurut Sudjana, (2000:22) hasil belajar adalah kemampuan-kemampuan yang dimiliki peserta didik setelah ia menerima 
pengalaman belajar. Hasil belajar disini diartikan sebagai suatu gambaran hasil belajar yang mencakup aspek kognitif, psikomotorik dan afektif peserta didik dalam mengikuti proses belajar mengajar pada suatu jenjang yang diikutinya. Tujuan kegiatan belajar ialah perubahan tingkah laku, baik yang menyangkut pengetahuan, keterampilan, sikap, bahkan meliputi segenap aspek pribadi. Pendapat tentang hasil belajar dikemukakan oleh Briggs dalam Taruh (2003:17) yang mengatakan bahwa hasil belajar adalah "seluruh kecakapan dan hasil dicapai melalui proses belajar mengajar di sekolah yang menyatakan dengan angka-angka atu nilainilai berdasarkan tes hasil belajar".

Berdasarkan pengertian diatas, maka dapat disimpulkan bahwa hasil belajar adalaha perubahan tingkat perkembangan mental dan kemampuan-kemampuan yang dimiliki peserta didik setelah menerima pengalaman belajarnya yang lebih baik jika dibandingkan pada saat sebelum belajar yang mencakup ranah kognitif, afektif, dan psikomotorik.. serta perubahan kemampuan yang terjadi dalam diri peserta didik yang ditandai dengan perubahan tingkah laku secara kuantitatif dalam bentuk seperti penguasaan, pengetahuan atau pemahaman, keterampilan, analisis, evaluasi, serta nilai dan hasil belajar.

a. Faktor-faktor yang Mempengaruhi Hasil Belajar

Hasil belajar sebagai salah satu indikator pencapaian tujuan pembelajaran di kelas tidak terlepas dari faktor-faktor yang mempengaruhi hasil belajar itu sendiri. Yudhi Munandi (2008:24) menyatakan bahwa "faktor-faktor yang mempengaruhi hasil belajar peserta didik dibagi menjadi dua klasifikasi, yaitu : 1) faktor-faktor intern, 2) faktor-faktor ekstern. Faktor-faktor yang mempengaruhi hasil belajar tersebut.

\section{Pembelajaran IPS di SD}

a. Pengertian mata pelajaran IPS di SD

Depertemen Pendidikan Nasional

(Pusat Kurikulum, 206: 7) mendefenisikan IPS sebagai berikut :

Ilmu Pengetahuan Sosial (IPS) merupakan integrasi dari berbagai cabang ilmu-ilmu sosial seperti : sosiologi, sejarah, geografi, ekonomi, politik, hukum, dan budaya. Ilmu Pengetahuan Sosial dirumuskan atas dasar realitas dan fenomena sosial yang mewujudkan satu pendekatan interdisipliner dari aspek dan cabangcabang ilmu-ilmu sosial (sosiologi, sejarah, geografi, ekonomi, politik, hukum, dan budaya).

Dengan demikian peserta didik yang mempelajari IPS dapat menghayati masa sekarang dengan dibekali pengetahuan tentang masa lampau umat manusia bertolak dari uraian tersebut, kegiatan belajar mengajar IPS membahas manusia dengan lingkungannya dari berbagi sudut ilmu sosial pada lampau, sekarang, dan masa mendatang, baik pada lingkungan yang dekat maupun lingkungan yang jauh dari peserta didik.

b. Tujuan Pembelajaran IPS SD

Sapriya (2015: 194) mengemukakan tentang tujuan pelajaran IPS SD sebagai berikut :

1) Mengenal konsep-konsep yang berhungan dengan kejadian dan peristiwa yang terjadi dalam masyarakat dan lingkungannya.

2) Memiliki kemampuan dasar untuk berpikir kritis dan logis, memiliki rasa ingin tahu, inquiri, dan mampu memecahkan masalah dan keterampilan dalam kehidupan bermasyarakat.

3) Memiliki komitmen dan kesadaran terhadap terhadap nilai-nilai sosial dan kemanusiaan.

4) Memiliki kemampuan berkomunikasi, bekerja sama dan berkompetisi dalam masyarakat yang menjemuk, di tingkat lokal, nasional, dan global.

Sejalan dengan tujuan tersebut tujuan pendidikan IPS menurut Sudardisastra ( Rahman Tammeng: 2012) adalah membina peserta didik menjadi warga negara yang baik, yang memiliki pengetahuan, keterampilan, dan kepedulian sosial yang berguna bagi dirinya serta bagi masyarakat dan negara. Secara rinci Suradisastra (1993) merumuskan tujuan pendidikan IPS sebagai berikut :

1) Pengetahuan dan Pemahaman

Salah satu fungsi pengajaran IPS adalah mentransmisikan pengetahuan dan pemahaman tentang masyarakat berupa fakta dan ide-ide kepada peserta didik. 
2) Sikap Belajar

IPS juga bertujuan mengembangkan sikap belajar yang baik artinya dengan belajar IPS peserta didik memiliki kemampuan menyelidiki (inkuiri) untuk menemukan ide-ide, konsep-konsep baru sehingga mereka mampu melakukan prespektif untuk masa yang akan datang.

3) Nilai-Nilai Sosial dan Sikap

Peserta didik membutuhkan nilai-nilai untuk menafsirkan fenomena dunia sekitarnya, sehingga mereka mampu melakukan prespektif. Nilai-nilai sosial merupakan unsur penting di dalam pengajaran pengajaran IPS.

Faktor keluarga, masyarakat, dan kepribadian/tingkah laku guru, besar pengaruhnya terhadap perkembangan nilai-nilai dan sikap peserta didik.

\section{Problem Based Learning (PBL)}

\section{a. Pengertian Problem-Based Learning $(P B L)$}

Pengajaran berdasarkan masalah ini telah dikenal sejak zaman John Dewey. Menurut Dewey (dalam Trianto, 2009:91) belajar berdasarkan masalah adalah interaksi antara stimulus dan respon, merupakan hubungan antara dua arah belajar dan lingkungan. Lingkungan memberikan masukan kepada peserta didik berupa bantuan dan masalah, sedangkan sistem saraf otak berfungsi menafsirkan bantuan itu secara efektif sehingga masalah yang dihadapi dapat diselidiki, dinilai, dianalisis, serta dicari pemecahannya dengan baik. Pembelajaran Berbasis Masalah yang brasal dari bahasa Inggris Problem-based Learning adalah suatu pendekatan pembelajaran yang dimulai dengan menyelesaikan suatu masalah, tetapi untuk menyelesaikan masalah itu peserta didik memerlukan pengetahuan baru untuk dapat menyelesaikannya. Pendekatan pembelajaran berbasis masalah (problem-based learning / PBL) adalah konsep pembelajaran yang membantu guru menciptakan lingkungan pembelajaran yang dimulai dengan masalah yang penting dan relevan (bersangkut-paut) bagi peserta didik, dan memungkinkan peserta didik memperoleh pengalaman belajar yang lebih realistik (nyata). Pembelajaran Berbasis
Masalah melibatkan peserta didik dalam proses pembelajaran yang aktif, kolaboratif, berpusat kepada peserta didik, yang mengembangkan kemampuan pemecahan masalah dan kemampuan belajar mandiri yang diperlukan untuk menghadapi tantangan dalam kehidupan dan karier, dalam lingkungan yang bertambah kompleks sekarang ini. Pembelajaran Berbasis Masalah dapat pula dimulai dengan melakukan kerja kelompok antar peserta didik. peserta didik menyelidiki sendiri, menemukan permasalahan, kemudian menyelesaikan masalahnya di bawah petunjuk fasilitator (guru). Pembelajaran berbasis masalah (Problem-based learning), selanjutnya disingkat PBL, merupakan salah satu model pembelajaran inovatif yang dapat memberikan kondisi belajar aktif kepada peserta didik. PBL adalah suatu model pembelajaran yang, melibatkan peserta didik untuk memecahkan suatu masalah melalui tahap-tahap metode ilmiah sehingga peserta didik dapat mempelajari pengetahuan yang berhubungan dengan masalah tersebut dan sekaligus memiliki ketrampilan untuk memecahkan masalah.

\section{b. Karakteristik Problem-Based Learning (PBL)}

Problem Based Learning mempunyai karakteristik-karakteristik sebagai berikut:

1. Pelajaran berfokus pada pemecahan masalah

Kracjik \& Blumenfeld (dalam Eggen dkk, 2012:307) mengatakan bahwa kegiatan Problem Based Learningbermula dari satu masalah dan memecahkannya adalah fokus pembelajarannya. Langkah awal dari pembelajaranberdasar masalah adalah mengajukanmasalah, selanjutnya berdasarkan masalah ditemukan konsep, prinsip serta aturan-aturan.Masalah yang diajukan secara autentik ditujukan dengan memacu padakehidupan riil.

2. Tanggung jawab untuk memecahkan masalah bertumpu pada siswa

Menurut Eggen dkk (2012:307) Problem Based Learning dilaksanakan dalam kelompok yang cukup kecil, 
sehingga semua siswa terlibat dalam proses itu. Dengan membuat siswa terlibat dalam proses dan tanggung jawab dalam pembelajaran mereka sendiri, keuntungan yang mereka dapat lebih luas cakupannya dan mereka bisa menyalurkan serta menambah kemampuannya seperti kemampuan berkomunikasi, kerja tim sertamemecahkan masalah.

3. Guru mendukung proses saat siswa mengerjakan masalah.

$$
\text { Eggen } \mathrm{dkk}
$$

mengemukakan bahwa peran guru dalam menuntun siswa sangat penting. Hal ini bisa dilakukan dengan mengajukan pertanyaan dan memberikan dukungan pengajaran lain saat siswa berusaha memecahkan masalah. Jika guru tidak memberikan cukup bimbingan dan dukungan, siswa akan gagal, membuang waktu dan mungkin memunculkan pemikiran yang salah. Tetapi jika berlebihan siswa tidak akan mendapat banyak pengalaman dalam pemecahan masalah.

\section{c. Langkah-langkah Learning (PBL)}

Problem-Based

Sugiyono, (2010:159), menjelaskan ada 5 tahapan dalam model problem-based learning dan prilaku yang dibutuhkan guru. Langkah-langkah itu adalah sebagai berikut:

1) Tahap 1, yaitu orientasi siswa pada masalah.

2) Tahap 2, yaitu mengorganisasi siswa untuk belajar.

3) Tahap 3, yaitu membimbing penyelidikan individual maupun kelompok.

4) Tahap 4, yaitu mengembangkan dan menyajikan hasil karya.

5) Tahap 5, yaitu menganalisis dan mengevaluasi proses pemecahan masalah

Model pembelajaran berdasar masalah (PBL) berlangsung dalam enam fase, yaitu:

Fase 1: Pengajuan permasalahan. Soal yang diajukan seperti dinyatakan sebelumnya harus tidak terstrktur dengan baik, dalam arti untuk penyelesaiannya diperlukan infoemasi atau data lebih lanjut, memungkinkan banyak cara atau jawaban, dan cukup luas kandungan materinya.

Fase2: Apa yang diketahui diketahui dari permasalahan? Dalam fase ini setiap anggota akan melihat permasalahan dari segi pengetahuan yang telah dimiliki sebelumnya. Kelompok akan mendiskusikan dan menyepakati batasan-batasan mengenai permasalahan tersebut, serta memilahmemilah isu-isu dan aspek-aspek yang cukup beralasan untuk diselidiki lebih lanjut. Analisis awal ini harus menghasilkan titik awal untuk penyelidikan dan dapat direvisi apabila suatu asumsi dipertanyakan atau informasi baru muncul kepermukaan.

Fase 3: Apa yang tidak diketahui dari permasalahan? Disini anggota kelompok akan membuat daftar pertanyaan-pertanyaan atau isu-isu pembelajaran yang harus dijawab untuk menjelas permasalahan. Dalam fase ini, anggota kelompok akan mengurai permasalahan menjadi komponen-komponen, mendiskusikan implikasinya, mengajukan berbagai penjelasan atau solusi, dan mengembangkan hipotesis kerja. Kegiatan ini seperti fase "brainstorming" dengan evaluasi; penjelasan atau solusi dicatat. Kelompok perlu merumuskan tujuan pembelajaran, menentukan informasi yang dibutuhkan, dan bagaimana informasi ini diperoleh.

Fase 4: Alternatif Pemecahan. Dalam fase ini anggota kelompok akan mendiskusikan, mengevaluasi, dan mengorganisir hipotesis dan mengubah hipotesis. Kelompok akan membuat daftar "Apa yang harus dilakukan?" yang mengarah kepada sumberdaya yang dibutuhkan, orang yang akan dihubungi, artikel yang akan dibaca, dan tindakan yang perlu dilakukan oleh para anggota. Dalam fase ini anggota kelompok akan menentukan dan mengalokasikan tugas-tugas, mengembangkan rencana untuk mendapatkan informasi yang dibutuhkan. Informasi tersebut dapat berasal dari dalam kelas, bahan bacaan, buku pelajaran, perpustakaan, perusahaan, video, dan dari seorang pakar tertentu. Bila ada informasi baru, kelompok perlu menganalisa dan mengevaluasi reliabilitas dan 
kegunaannya untuk penyelesaian permasalahan yang sedang dihadapi.

Fase 5: Laporan dan Presentasi Hasil. Pada fase ini, setiap kelompok akan menulis laporan hasil kerja kelompoknya. Laporan ini memuat hasil kerja kelompok dalam fase-fase sebelumnya diikuti dengan alasan mengapa suatu alternatif dipilih dan uraian tentang alternatif tersebut. Pada bagian akhir setiap kelompok menjelaskan konsep yang terkandung dalam permasalahan yang diajukan dan penyelesaian yang mereka ajukan. Misalnya, rumus apa yang mereka gunakan. Laporan ini kemudian dipresentasikan dan didiskusikan dihadapan semua siswa.

Fase 6: Pengembangan Materi. Dalam fase ini guru akan mengembangkan materi yang akan dipelajari lebih lanjut dan mendalam dan memfasilitasi pembelajaran berdasarkan konsep-konsep yang diajukan oleh setiap kelompok dalam laporannya.

\section{d. Tujuan Problem-Based Learning (PBL)}

Widodo, (2009: 4) mengemukakan bahwa PBL utamanya dikembangkan untuk membantu siswa mengembangkan kemampuan berpikir, pemecahan masalah dan keterampilan intelektual, belajar berbagai peran orang dewasa dengan melibatkan mereka dalam pengalaman nyata atau simulasi.

Model PBL lebih menekankan pada kreatifan seorang siswa dalam mengembangkan kemampuannya berpikir dan memecahkan masalah, tanpa harus mengandalkan guru hanya sebagai fasilitator yang tidak memberikan informasi sebanyakbanyaknya kepada siswa.

Adapun tujuan pembelajaran berbasis masalah (problem based learning) adalah sebagai berikut :

1) Membantu siswa mengembangkan kemampuan berpikir dan keterampilan pemecahan masalah

2) Belajar peranan orang dewasa yang autentik

3) Menjadi pemelajar yang mandiri

e. Kelebihan dan kekurangan ProblemBased Learning (PBL)

1) Pembelajaran Problem Based Learning atau berdasarkan masalah memiliki beberapa kelebihan dibandingkan dengan model pembelajaran yang lainnya, di antaranya sebagai berikut:

a. Pemecahan masalah merupakan teknik yang cukup bagus untuk memahami isi pelajaran.

b. Pemecahan masalah dapat menantang kemampuan siswa serta memberikan kepuasan uniituk menemukan pengetahuan baru bagi siswa.

c. Pemecahan masalah dapat meningkatkan aktivitas pembelajaran siswa

2) Sama halnya dengan model pengajaran yang lain, model pembelajaran Problem Based Learning juga memiliki beberapa kekurangan dalam penerapannya. Kelemahan tersebut diantaranya:

a. Manakala siswa tidak memiliki minat atau tidak memiliki kepercayaan bahwa masalah yang dipelajari sulit untuk dipecahkan, maka mereka akan merasa enggan untuk mencoba

b. Keberhasilan strategi pembelajaran malalui Problem Based Learning membutuhkan cukup waktu untuk persiapan

c. Tanpa pemahaman mengapa mereka berusaha untuk memecahkan masalah yang sedang dipelajari, maka mereka tidak akan belajar apa yang mereka ingin pelajari.

\section{Pendekatan Saintifik}

\section{a. Pengertian Pendekatan saintifik}

Pembelajaran dengan pendekatan saintifik adalah proses pembelajaran yang dirancang sedemikian rupa agar peserta didik secara aktif mengkonstruk konsep, hukum atau prinsip melalui tahapantahapan mengamati (untuk mengidentifikasi atau menemukan masalah), merumuskan masalah, mengajukan atau merumuskan hipotesis, mengumpulkan data dengan berbagai teknik, menganalisis data, menarik kesimpulan dan mengkomunikasikan konsep, hukum atau prinsip yang "ditemukan" (Kurinasih, 2014:29) . Pendekatan saintifik dimaksudkan memberikan pemahaman kepada peserta 
didik dalam mengenal, memahami berbagai materi menggunakan pendekatan ilmiah, bahwa informasi bisa berasal dari mana saja, kapan saja, tidak bergantung pada infromasi searah guru. Oleh karena itu kondisi pembelajaran yang diharapkan tercipta diarahkan untuk mendorong peserta didik dalam mencari tahu dari berbagai sumber melalui observasi dan bukan hanya diberi tahu.

\section{b. Tujuan Pembelajaran dengan pendekatan saintifik}

Tujuan pembelajaran dengan pendekatan saintifik didasarkan pada keunggulan pendekatan tersebut. Beberapa tujuan pembelajaran dengan pendekatan saintifik adalah sebagai berikut.

1. Untuk meningkatkan kemampuan intelek, khususnya kemampuan berpikir tingkat tinggi siswa;

2. Untuk membentuk kemampuan siswa dalam menyelesaikan suatu masalah secara sistematik;

3. Terciptanya kondisi pembelajaran dimana siswa merasa bahwa belajar itu merupakan suatu kebutuhan;

4. Diperolehnya hasil belajar yang tinggi;

5. Untuk melatih siswa dalam mengkomunikasikan ide-ide khususnya dalam menulis artikel ilmiah;

6. Untuk mengembangkan karakter siswa.

\section{c. Langkah-langkah Pembelajaran dengan Pendekatan Saintifik}

Langkah-langkah pendekatan saintifik dalam proses pembelajaran meliputi menggali informasi melalui pengamatan, bertanya, percobaan, kemudian mengolah data atau informasi, menyajikan data atau informasi, dilanjutkan dengan menganalisis, menalar, kemudian menyimpulkan, dan mencipta (Kurinasih, 2014:30). Untuk mata pelajaran, materi, atau situasi tertentu, sangat mungkin pendekatan ilmiah ini tidak selalu tepat diaplikasikan secara prosedural. Pada kondisi seperti ini, tentu saja proses pembelajaran harus tetap menerapkan nilainilai atau sifat-sifat ilmiah dan menghindari nilai-nilai aau sifat-sifat nonilmiah. Pendekatan saintifik dalam pendekatan saintifik disajikan sebagai berikut.

\section{Pendekatan Konvensional}

a. Pengertian pendekatan Konvensional

Pendekatan pembelajaran konvensional adalah pendekatan pembelajaran yang sudah terjadi / berlaku di sekolah selama ini. Pembelajaran yang terjadi di sekolah-sekolah masih mengikuti pola sekolah dengan guru datang, menyampaikan bahan pelajaran yang telah dipersiapkan. Siswa mendegarkan dan mencatat pelajaran seteliti mungkin.

\section{b. Sumber Belajar Pendekatan Konvensional \\ Sumber belajar dalam pendekatan} pembelajaran konvensional lebih banyak berupa informasi verbal yang diperoleh dari buku dan penjelasan guru atau ahli. Sumber-sumber inilah yang sangat mempengaruhi proses belajar siswa. Oleh karena itu, sumber belajar (informasi) harus tersusun secara sistematis mengikuti urutan dari komponen-komponen yang kecil ke besar dan biasanya bersifat deduktif.

Implementasi program pembelajaran terdiri dari langkah-langkah, yaitu:

1. apersepsi,

2. penjelasan konsep, dengan metode ceramah dan/atau demonstrasi,

3. latihan terbimbing,

4. memberikan balikan.

Keseluruhan pelaksanaan langkah-langkah pembelajaran ini menggunakan latar (seting) belajar diskusi kelompok-kelompok kooperatif.

\section{c. Kelebihan dan Kekuranga Pendekatan Konvensional \\ Keunggulan pendekatan konvensional}

1. Mengajar terencana, isi silabus dapat diselesaikan menurut waktu yang tersedia.

2. Dapat dilaksanakan pada kelas besar maupun kelas kecil.

3. Tidak terlalu banyak memerlukan alat bantu.

4. Dapat dipakai sebagai penambah bahan baca.

\section{Kelemahan pendekatan konvensional}

1. Menghalangi respon yang mengajar. 
2. Hanya sedikit pengajar yang dapat menjadi pembicara yang baik.

3. Pembicara harus menguasai pokok pembicaraannya.

4. Membatasi daya ingat siswa.

\section{METODE PENELITIAN}

\section{Jenis dan Desain Penelitian}

1. Jenis Penelitian

Penelitian ini menggunakan jenis penelitian Eksperimen dengan pendekatan Quasi Experimental Design.

2. Desain Penelitian

Desain penelitian menggunakan desain kelompok kontrol nonekuivalen. Ibnu Hadjar (1996:334), menjelaskan bahwa desain penelitian nonekuivalen disajikan pada tabel berikut:

Tabel. 3.1

Desain penelitian

\begin{tabular}{|l|l|l|l|}
\hline Eksperimen & $O_{1}$ & $X_{1}$ & $O_{2}$ \\
\hline & & & \\
Kontrol & $O_{1}$ & $X_{0}$ & $O_{2}$ \\
\hline
\end{tabular}

keterangan :

$O_{1}:$ Pretest

$\mathrm{O}_{2}:$ Posttest

$X_{1}$ : Perlakuan ( Pembelajaran IPS menggunakan Model Problem Based Learning dengan Pendekatan Saintifik)

$X_{0}$ : Pembelajan IPS dengan menggunakan Model Problem Based Learning dengan Pendekatan Konvesional.

\section{Tempat dan Waktu Penelitian}

a. Tempat Penelitian

Penelitian ini dilaksanakan di SDN 197 Duampanua Kabupaten Pinrang.

b. Waktu Penelitian

Penelitian ini dilaksanakan dengan pretest terlebih dahulu kemudian di beri pembelajaran IPS sebanyak 3 sampai 4 kali pertemuan di setiap kelas lalu diberikan posttest. Dimana kelas kontrol diajar dengan Model Problem Based Learning dengan Pendekatan konvensional dan kelas eksperimen dengan Model Problem Based Learning dengan Pendekan Saintifik.

\section{Variabel dan Defenisi Oprasional Penelitian}

a. Variabel penelitian

Penelitian ini terdiri dari tiga variabel, satu variabel terikat (dependent) dan dua variabel bebas (independent). Ada pun variabelnya sebagai berikut :

Y : Hasil Belajar Peserta Didik (Variabel Dependent)

$\mathrm{X}_{1}$ : Model Problem Based Learning dengan Pendekatan Saintifik

(Variabel Independent)

$\mathrm{X}_{2}$ : Model Problem Based Learning dengan

Pendekatan

Konvensional (Variabel

Independent)

b. Defenisi Oprasional Penelitian

. Untuk lebih memperjelas pemahaman dan menyamakan persepsi sehingga tidak terjadi perbedaan dalam memahami variabel penelitian yang akan diteliti.

Dalam penelitian ini yang menjadi defenisi oprasional adalah :

1. Pendekatan saintifik

2. Model Problem-Based Learning (PBL)

3. Hasil belajar IPS

\section{Populasi dan Sampel}

Populasi

Menurut Sugiyono (2010: 117) bahwa: "Populasi adalah wilayah generalisasi yang terdiri atas;objek/subjek yang mempunyai kualitas dan karakteristik tertentu yang diterapkan oleh peneliti untuk dipelajari dan kemudian ditarik kesimpulannya". Dari pengertian populasi yang telah dikemukakan di atas dapatlah disimpulkan bahwa populasi merupakan keseluruhan yang menjadi objek penelitian. Jadi pada dasarnya populasi merupakan keseluruhan objek penelitian. Populasi dalam penelitian ini adalah seluruh peserta didik SDN 197 Duampanua Kabupaten Pinrang.

Sampel

Sampel yang digunakan dalam penelitian ini adalah Kelas V A dan V B SDN 197 Duampanua yang terdiri dari 23 peserta 
didik untuk setiap kelasnya .sehingga didapatkan Kelas VA sebagai kelas eksperimen dan Kelas V B sebagai kelompok kelas kontrol.

\section{Instrumen Penelitian}

Instrumen penelitian yang digunakan dalam penelitian ini yaitu instrumen hasil belajar peserta didik dan lembar observasi.

a. Tes Tulis

b. Lembar Observasi.

\section{Teknik Pengumpulan Data}
a. Tes
b. Observasi
c. Dokumentasi

\section{Hipotesis Statistik}

Perumusan hipotesis statistik dalam penelitian ini adalah sebagai berikut :

\begin{tabular}{l}
$\mathrm{H}_{1}: \mu_{1}=\mu_{2}$ \\
$\mathrm{H}_{2}: \mu_{1} \neq \mu_{2}$ \\
Keterangan: \\
$\mathrm{H}_{1} \quad$ Rata-rata hasil belajar IPS \\
siswa melalui penerapan Model \\
\multicolumn{4}{c}{ Problem Based Learning } \\
dengan Pendekatan Saintifik. \\
$\mathrm{H}_{2} \quad=$ Rata-rata hasil belajar IPS \\
siswa melalui penerapan Model \\
Problem Based Learning \\
dengan Pendekatan Konvensional
\end{tabular}

\section{Teknik Analisis Data}

Untuk menganalisis data yang diperoleh dari hasil penelitian digunakan analisis statistik deskriptif dan inferensial.

1. Statistik Deskriptif

2. Statistik Inferensial

\section{HASIL DAN PEMBAHASAN}

\section{Hasil Penelitian}

1. Hasil Belajar IPS Peserta Didik Kelas V SDN 197 Duampanua Kabupaten Pinrang yang Diajar Melalui Model Problem Based Learning (PBL) dengan Pendekatan Saintifik

Hasil Belajar IPS Peserta Didik Sebelum diberi Perlakuan (Pretest).
Berdasarkan data hasil belajar IPS peserta didik pada pretest terlihat bahwa pada nilai mean yaitu 48,26 , median yaitu 50 , dan modus yaitu 40. Sedangkan standar deviasinya adalah 13,02. Nilai minimun peserta didik adalah 30 sedangkan nilai maksimunnya peserta didik adalah 70. Dapat kita lihat dari 23 orang peserta didik yang menjadi sampel penelitian tidak terdapat peserta didik yang berada pada kategori tinggi dan sangat tinggi atau $0 \%, 3$ orang peserta didik yang berada pada kategori rendah sedang atau 13,04\%. 4 orang peserta didik yang berada pada kategori rendah atau $17,40 \%$. 16 orang peserta didik yang berada pada kategori sangat rendah atau $69,56 \%$. Berikut ini ditampilkan diagram balok hasil analisis pretest peserta didik.

Deskripsi Hasil Belajar IPS Peserta

Didik Setelah Perlakuan (Posttest).

Berdasarkan data hasil belajar IPS peserta didik pada pretest terlihat bahwa pada nilai mean 88,70, median 90, dan modus 80 , nilai minimun peserta didik 80 dan nilai maksimunnya 100. Dapat kita lihat dari 23 orang peserta didik yang menjadi sampel penelitian terdapat 14 orang peserta didik yang berada pada kategori sangat tinggi atau $60,87 \%$, dan 9 orang peserta didik yang berada pada kategori tinggi atau 39,13\%, dan tidak ada peserta didik berada pada kategori sedang, rendah, ataupun sangat rendah.

Hasil belajar IPS peserta didik setelah penggunaan Model Problem Based Learning dengan Pendekatan Saintifik tergolong kategori sangat tinggi sebanyak 14 peserta didik atau $60,87 \%$. Ini berarti bahwa setelah penggunaan Model Problem Based Learning dengan Pendekatan Saintifik, mereka memiliki hasil belajar yang tinggi terhadap materi pembelajaran IPS yang diberikan. Hal ini mengindikasikan bahwa setelah penggunaan Model Problem Based Learning dengan Pendekatn Saintifik berpengaruh lebih baik untuk meningkatkan hasil belajar peserta didik daripada kelas yang tidak menggunakan Model Problem Based Learning dengan Pendekatn Saintifik.

2. Hasil Belajar IPS Peserta Didik Kelas V SDN 197 Duampanua Kabupaten Pinrang yang Diajar Melalui Model Problem Based Learning (PBL) dengan Pendekatan Konvensional. 


\section{Deskripsi Hasil Belajar IPS Peserta Didik Sebelum diberi Perlakuan (Pretest) \\ Berdasarkan data hasil belajar IPS} peserta didik pada pretest atau sebelum penggunaan Model Problem Based Learning dengan Pendekatan Konvensional terlihat bahwa dari ukuran sampel 23 tedapat nilai mean 47,39, median 50, dan modus 50 dan nilai minimun siswa 30 sedangkan nilai maksimunnya 70 . Dapat kita lihat dari 23 orang peserta didik yang menjadi sampel penelitian tidak terdapat peserta didik yang berada pada kategori sangat tinggi dan kategori tinggi atau $0 \%, 2$ orang peserta didik yang berada pada kategori sedang atau $8,70 \%$. 4 orang peserta didik yang berada pada kategori rendah atau 17,40\%. 17 orang peserta didik yang berada pada kategori sangat rendah atau $73,91 \%$.

\section{Deskripsi Hasil Belajar IPS Peserta Didik Setelah Perlakuan (Posttest). \\ Berdasarkan data hasil belajar IPS} peserta didik pada pretest terlihat bahwa pada nilai mean 75,65 , median 70 , dan modus 70 , nilai minimun siswa 70 dan nilai maksimunnya 100.

Dapat kita lihat dari 23 orang peserta didik yang menjadi sampel penelitian terdapat 3 orang peserta didik yang berada pada kategori sangat tinggi atau 13,04\%, 6 orang peserta didik yang berada pada kategori tinggi atau 26,10\%, 14 orang peserta didik yang berada pada kategori sedang atau $60,86 \%$, dan tidak ada peserta didik berada pada kategori rendah, ataupun sangat rendah. Hasil belajar IPS peserta didik setelah penggunaan Model Problem Based Learning dengan Pendekatan Konvensional tergolong kategori sedang sebanyak 14 orang peserta didik atau $60,86 \%$. Ini berarti bahwa setelah penggunaan Model Problem Based Learning dengan Pendekatan Konvensional, mereka memiliki hasil belajar yang sedang terhadap materi pembelajaran IPS yang diberikan.

\section{Pembahasan Hasil Penelitian}

\section{Hasil Belajar IPS Peserta Didik Kelas V} SDN 197 Duampanua Kabupaten Pinrang yang Diajar Melalui Model Problem Based Learning (PBL) dengan Pendekatan Saintifik.

Setelah melakukan uji statistik pada hasil belajar peserta didik pada kelompok Eksperimen yaitu kelompok Peserta didik yang diajar melalui model Problem Based Learning dengan pendekatan Saintifik. Adapun hasil analisis deskrptif data menunjukkan perbedaan ratarata hasil belajar IPS Va (kelas Eksperimen) yang diajar sebelum dan sesudah diajarkan dengan melalui model Problem Based Learning dengan pendekatan Saintifik. yaitu nilai rata-rata pretest hasil belajar IPS melalui model Problem Based Learning dengan pendekatan Saintifik yaitu 48,26 sedangkan nilai rata-rata posttest hasil belajar malalui model Problem Based Learning dengan pendekatan Saintifik sebesar 88,70.

\section{Hasil Belajar IPS Peserta Didik Kelas V} SDN 197 Duampanua Kabupaten Pinrang yang Diajar Melalui Model Problem Based Learning (PBL) dengan Pendekatan Konvensional.

Setelah melakukan uji statistik pada hasil belajar peserta didik pada kelompok Kontrol yaitu kelompok Peserta didik yang diajar melalui model Problem Based Learning dengan pendekatan Konvensional. Adapun hasil analisis deskrptif data menunjukkan perbedaan rata-hasil belajar IPS Vb (kelas Kontrol) yang diajar sebelum dan sesudah diajarkan dengan melalui model Problem Based Learning dengan pendekatan konvensional yaitu nilai rata-rata pretest hasil belajar IPS melalui model Problem Based Learning dengan pendekatan Konvensional yaitu 47,39 sedangkan nilai ratarata posttest hasil belajar malalui model Problem Based Learning dengan pendekatan Konvensional sebesar 76,65. Hasil analisis data menunjukkan bahwa rata-rata hasil belajar pesrta didik yang diperoleh melalui tes akhir setelah pembelajaran IPS malaui model Problem Based Learning dengan pendekatan Konvensional yaitu berada pada kategori sedang.

3. Perbedaan Hasil Belajar IPS Peserta Didik Kelas V SDN 197 Duampanua Kabupaten Pinrang Antara yang Diajar Model Problem Based Learning dengan pendekatan Saintifik dan Model Problem Based Learning dengan pendekatan Konvensional

Setelah penerapan Model Problem Based Learning dengan Pendekatan Saintifik dan Model Problem Based Learning dengan Pendekatan Konvensional dapat dilihat bahwa 
terdapat perbedaan hasil belajar peserta didik setelah diberi perlakuan (posttest), dimana nilai hasil belajar IPS peserta didik setelah perlakuan dikelas dengan penerapan Model Problem Based Learning dengan Pendekatan Konvensional dengan nilai rata-rata yaitu 76,65 memiliki nilai yang rendah dibandingkan dengan kelas yang mendapat perlakuan dengan Model Problem Based Learning dengan Pendekatan Saintifik dengan nilai rata-rata sebasar 88,70 . Itu berarti bahwa penerapan Model Problem Based Learning dengan Pendekatan Saintifik lebih baik daripada Model Problem Based Learning dengan Pendekatan Konvensional serta lebih mampu meningkatkan hasil belajar IPS.

\section{SIMPULAN DAN SARAN}

\section{Kesimpulan}

Berdasarkan hasil analisis data secara deskriptif maupun inferensial dan pembahasan hasil penelitian maka dikemukakan kesimpulan sebagai berikut:

1. Hasil belajar IPS sebelum perlakuan (pretest) menggunakan Model Problem Based Learning dengan Pendekatan Saintifik, umumnya berada pada kategori sangat rendah. Namun setelah diberi perlakuan menggunakan Model Problem Based Learning dengan Pendekatan Saintifik, maka hasil belajar IPS peserta didik berada pada kategori sangat tinggi.

2. Hasil belajar IPS sebelum perlakuan (pretest) menggunakan Model Problem Based Learning dengan Pendekatan Konvensional, umumnya berada pada kategori sangat rendah. Namun setelah diberi perlakuan menggunakan Model Problem Based Learning dengan Pendekatan konvensional, maka hasil belajar IPS peserta didik umumnya berada pada kategori Sedang.

3. Terdapat terdapat perbedaan hasil belajar IPS yang diajar menggunakan Model Problem Based Learning dengan Pendekatan Saintifik dan hasil belajar IPS yang diajar menggunakan Model Problem Based Learning dengan Pendekatan Konvensional di kelas V SDN 197 Duampanua Kabupaten Pinrang. Perbedaan ini menjadi dasar acuan untuk menarik kesimpulan bahwa terdapat pengaruh
Model Problem Based Learning dengan Pendekatan Saintifik terhadap hasil belajar IPS peserta didik kelas V SDN 197 Duampanua Kabupaten Pinrang..

\section{Saran}

Sesuai dengan kesimpulan tersebut, maka dapat diajukan beberapa saran yaitu :

1. Guru hendaknya dalam proses pembelajaran jangan hanya menjelaskan kepada peserta didik tentang materi yang ada dan membuat peserta didik hanya mendengarkan dan mencatat apa saja yang dijelaskan oleh guru, tetapi guru hendaknya dapat menerapkan Model Problem Based Learning dengan Pendekatan Saintifik sebagai salah satu alternatif dalam meminimalisir masalah hasil belajar sehingga peserta didik lebih aktif dalam proses pembelajaran.

2. Sebagai tindak lanjut penerapan, pada saat proses pembelajaran diharapkan guru untuk mengawasi dan mengontrol serta membimbing peserta didik dalam penerapan Model Problem Based Learning dengan Pendekatan Saintifik di kelas.

3. Kepada rekan- rekan mahasiswa dan peneliti selanjutnya agar dapat mengembangkan dan mengujicobakan Model Problem Based Learning dengan Pendekatan Saintifik pada materi dan permasalah yang berbeda agar dapat dijadikan sebagai bahan perbandingan.

\section{DAFTAR RUJUKAN}

Arikunto, S. (2003). Dasar-dasar Evaluasi Pendidikan (edisi revisi). Jakarta: PT Rineka Cipta

Eggen, Paul dan Kauchak, Don. (2012). Strategi dan Model Pembelajaran Mengajarkan Konten dan Keterampilan Berpikir. Jakarta: Indeks

Munandi, Y.(2008). Media Pembelajaran, Sebuah Pendekatan Baru. Jakarta: Gaung Persada Press.

Sugiyono. (2008). Metode Penelitian Pendidikan (Pendekatan Kuantitatif, 
Phinisi Integration Review. Vol 1(2) Agustus 2018

Kualitatif, dan $R \& D)$. Bandung: Alfabeta.

Sugiyono. (2009). Metode Penelitian Pendidikan. Bandung: Alfabeta

Sugiyono. (2012). Metode Penelitian Pendidikan (Pendekatan Kuantitatif, kualitatif, dan $R$ \& D). Bandung: Alfabeta

Sudjana. (2000). Metode Statistik, Tarsito. Bandung

Tukiran, T. Dkk. (2012). Metode-metode Pembelajaran Inovatif . Bandung: Alfabeta

Undang-Undang Republik Indonesia No. 20 tahun 2003 Tentang Sistem Pendidikan Nasional, (2003), Jakarta : Depdiknas

Uno, Hamzah B. (2009). Perencanaan Pembelajaran. Jakarta: Bumi Aksara

Yaba. (2006). Ilmu Pengetahuan Sosial 1. Program Studi Pendidikan Guru Sekolah Dasar Fakultas Ilmu Pendidikan Universitas Negeri Makassar. Makassar 